\title{
How Well Do Initial Claims Forecast Employment Growth Over the Business Cycle and Over Time?
}

\author{
Kevin L. Kliesen, Economist \\ David C. Wheelock, Vice President and Deputy Director of Research
}

\section{$\mathbf{L}$} abor market statistics are often scrutinized for insights about the strength of economic activity, especially when the economy appears to be faltering or in the early stages of a recovery. The initial claims for state unemployment insurance benefits, which are reported weekly by the Employment Training Administration of the Bureau of Labor Statistics, represent one such statistic. Initial claims measure labor flows from the ranks of the employed to the ranks of the unemployed (or vice versa) and are considered a leading indicator of economic activity, especially of the growth of employment. According to former Federal Reserve Chairman Alan Greenspan, initial claims are the "earliest clear indicator of what's happening to the

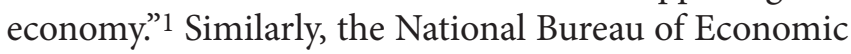
Research (NBER) Business Cycle Dating Committee states that "a bulge in jobless claims usually forecasts declining employment and rising unemployment."2

\section{Initial claims may now be useful for forecasting employment growth during periods of increasing economic activity.}

Although economists have argued that data on initial claims are useful for predicting monthly changes in payroll employment, empirical evidence has been mixed. ${ }^{3}$ In one study, McConnell found that adding initial claims to a simple forecasting model enhances 1-month-ahead forecasts of changes in total employment but only for recession months. ${ }^{4}$ Moreover, McConnell found that the augmented model produces worse forecasts of the change in total employment during expansion months than does a model that includes only lagged changes in employment.
McConnell estimated her model using data for 1952-97. The recoveries of employment following the recessions of 1990-91, 2001, and 2007-09, however, were unusually slow compared with most prior postwar U.S. recessions, suggesting that structural changes may have occurred in the labor market that, among other things, altered forecasting relationships. Before the 1990-91 recession, the economy typically grew rapidly during the early stages of recovery periods. The result was strong growth in employment and a rapidly falling unemployment rate. However, the slow recoveries of employment following the three most recent recessions suggest that structural changes have occurred in labor markets or the economy more broadly that have altered the speed with which employment recovers following recessions. Conceivably, then, if weak employment growth following recessions is the new normal, then the usefulness of initial claims for forecasting changes in employment may have also changed.

We reestimate McConnell's model using data for January 1952-November 2011 and examine forecast performance for recession months and expansion months separately. Further, we compare the forecasting performance of the model during recessions and expansions since 1989 with the performance of the model over 1952-89. The table reports the root mean squared errors (RMSEs) for the forecasting models that (i) include only lagged monthly changes in employment ("forecast without claims") and (ii) augment that model with the current monthly average of weekly data on initial unemployment claims ("forecast with claims"). The table also reports the probability that the difference in the RMSEs of the baseline and augmented models is due to random chance. For example, although the RMSE for the augmented model estimated over all months during 1952-89 is smaller than the RMSE for the baseline model, suggesting that the model augmented with initial claims produces more accurate forecasts of employ- 


\section{Initial Claims as a Forecasting Tool}

Root Mean Squared Error

\begin{tabular}{|c|c|c|c|}
\hline & \\
\hline & Full sample & Expansions & Recessions \\
\hline \multicolumn{4}{|l|}{ January 1952-December 1989} \\
\hline Forecast without claims & 161.34 & 159.35 & 169.91 \\
\hline Forecast with claims & 160.64 & 159.91 & 163.80 \\
\hline Difference (with claims - without claims) & -0.71 & 0.57 & -6.11 \\
\hline Probability that difference is due to random chance (\%) & 41.28 & 38.60 & 13.17 \\
\hline No. of months & 456 & 372 & 84 \\
\hline \multicolumn{4}{|l|}{ January 1990-November 2011} \\
\hline Forecast without claims & 119.44 & 115.56 & 140.86 \\
\hline Forecast with claims & 115.36 & 111.29 & 137.67 \\
\hline Difference (with claims - without claims) & -4.08 & -4.27 & -3.19 \\
\hline Probability that difference is due to random chance (\%) & 0.52 & 1.76 & 32.95 \\
\hline No. of months & 263 & 226 & 37 \\
\hline
\end{tabular}

NOTE: Predicted values for the model with claims and the model without claims were generated from the full January 1952-December 1989 and January 1990-November 2011 samples (all months used to preserve the time-series trend). Recession or expansion months were then eliminated accordingly, once the predicted values had been generated, to calculate the RMSEs.

ment growth, the probability that the difference in RMSEs is due to random chance is 41 percent, and hence the difference is not statistically significant by conventional criteria. ${ }^{5}$ Similar to the results in McConnell's study, we find that initial claims improve somewhat the ability of the model to forecast employment during recessions, though our results are not as strongly significant as hers, which were based on estimates for 1952-97.

Interestingly, we obtain quite different results when estimating the models using data for 1990-2011. For this period, initial claims produce statistically significant improvement in forecasts of employment growth during expansion months but not during recession months. The relatively few recession months during 1990-2011 caution against drawing strong conclusions; more research is needed to determine whether the apparent change in the usefulness of initial claims for forecasting employment growth at different phases of the business cycle since 1989 reflects fundamental changes in the structure of labor. Nevertheless, our finding suggests that initial claims may now be more useful for forecasting employment growth during periods of increasing economic activity rather than exclusively during periods of declining economic activity.

\begin{abstract}
Notes
${ }^{1}$ From Greenspan (2007, p. 8).

${ }^{2}$ See "The NBER's Business Cycle Dating Procedure: Frequently Asked Questions" at www.nber.org/cycles/recessions faq.html.

${ }^{3}$ See Gavin and Kliesen (2002) for an example and a description of the initial claims data.

${ }^{4}$ McConnell (1998) regressed the 1-month-ahead change in total nonfarm employment on 12 monthly lags of the change in employment and a constant. Her augmented model also included the current month's average of weekly data on initial claims.

${ }^{5}$ Following McConnell (1998), we use a test described in Diebold and Mariano (1995) to statistically compare the accuracy of the baseline and augmented models.
\end{abstract}

\section{References}

Diebold, Francis X. and Mariano, Roberto S. "Comparing Predictive Accuracy." Journal of Business and Economic Statistics, July 1995, 13(3), pp. 253-63.

Gavin, William T. and Kliesen, Kevin L. "Unemployment Insurance Claims and Economic Activity." Federal Reserve Bank of St. Louis Review, May/June 2002, 84(3), pp. 15-28;

http://research.stlouisfed.org/publications/review/02/05/15-28GavinKliesen.pdf. Greenspan, Alan. The Age of Turbulence: Adventures in a New World. New York: Penguin Press, 2007.

McConnell, Margaret M. "Rethinking the Value of Initial Claims as a Forecasting Tool." Federal Reserve Bank of New York Current Issues in Economics and Finance, November 1998, 4(11); http://app.ny.frb.org/research/current issues/ci4-11.pdf. 